\title{
Implementasi Algoritma Dijkstra Untuk Menentukan Jalur Terpendek Wilayah Pasar Minggu Dan STMIK Nusamandiri Jakarta
}

\author{
Supriadi Panggabean ${ }^{1}$, Windu Gata ${ }^{2}$, Arief Rama Syarif ${ }^{3}$, Siska Rahmadani ${ }^{4}$, \\ Tetra Widianto ${ }^{5}$ \\ 1,2,3,4,5 STMIK Nusa Mandiri Jakarta \\ e-mail: ${ }^{114002471 @ n u s a m a n d i r i . a c . i d, ~}{ }^{2}$ windu@nusamandiri.ac.id, \\ 3 arief.rma@nusamandiri.ac.id, 414002456@nusamandiri.ac.id, 514002461@nusamandiri.ac.id
}

\begin{abstract}
Abstraksi
Banyaknya urbanisasi penduduk membuat wilayah Jakarta menjadi sangat padat. Kepadatan tersebut sangat berpengaruh dengan kemacetan lalu lintas di Jakarta. Banyak cara yang sudah dilaksanakan oleh pemerintah DKI Jakarta untuk mengatasi masalah kemacetan. Akan tetapi, kemacetan tetap saja masih terjadi. Maka sebagai pengguna jalan harus mencari cara untuk mengatasi masalah tersebut. Salah satu cara yang efektif untuk digunakan adalah mencari rute alternatif terpendek yang dilalui dengan menggunakan Algoritma Dijkstra. Pemanfaatan Algoritma Dijkstra dapat digunakanan untuk menyelesaikan masalah ini karena Algoritma Dijkstra memberikan output berupa jalur terpendek dan tercepat dari dari titik awal menuju titik tujuan. Hasil pencarian rute terpendek antara kawasan Pasar Minggu dengan rute STMIK Nusa Mandiri Kramat Jakarta telah ditemukan yaitu rute ketiga dengan jarak tempuh 14,8 km.
\end{abstract}

Kata Kunci: Algoritma Dijkstra, implementasi, Rute terpendek.

\begin{abstract}
The large amount of urbanized residents has made the Jakarta area very dense. This density is very influential with congestion in Jakarta. There are many ways that have been done by the DKI Jakarta Provincial Government to solve congestion problems. However, congestion still occurs. So that as road users must find ways to overcome these problems. One of the effective ways to use it is to find the shortest alternative path which is followed by using Dijkstra's Algorithm. The use of Dijkstra's Algorithm can be used to solve this problem because the Dijkstra Algorithm provides output in the form of the shortest and fastest path from the starting point to the destination point. The results of the search for the shortest route between the Pasar Minggu area and the STMIK Nusa Mandiri Kramat Jakarta were found for the third route with a distance of $14.8 \mathrm{~km}$.
\end{abstract}

Keywords: Dijkstra's Algorithm, Implementation, Shortest route.

\section{Pendahuluan}

Algoritma merupakan suatu Langkah-langkah yang selalu digunakan dalam kehidupan sehari-hari. Secara tidak sadar algoritma juga digunakan dalam rutinitas sehari-hari dari bangun tidur sampai tidur kembali. Secara umumnya, algoritma adalah urutan langkah-langkah untuk menyelesaikan masalah (Munir, 2016). Selain digunakan dalam rutinitas kehidupan sehari-hari, algoritma juga digunakan sebagai alat pendukung berjalannya suatu sistem. Salah satu contoh algoritma yang digunakan adalah untuk mencari rute terpendek. Algoritma dijkstra adalah algoritma yang dapat digunakan dalam menentukan rute lintasan terpendek.

Algoritma dijkstra bertujuan untuk menentukan rute terpendek dari lintasan berdasarkan bobot terkecil dari satu titik ke titik berikutnya. Algoritma Dijkstra melakukan kalkulasi kemungkinan bobot terkecil terhadap setiap titik. Sesuai dengan namanya, penemu algoritma dijktrsa adalah seorang ilmuwan komputer dari Belanda yang bernama Edsger Dijkstra. Berikut ini adalah contoh pseudocode dari algoritma Dijkstra. 


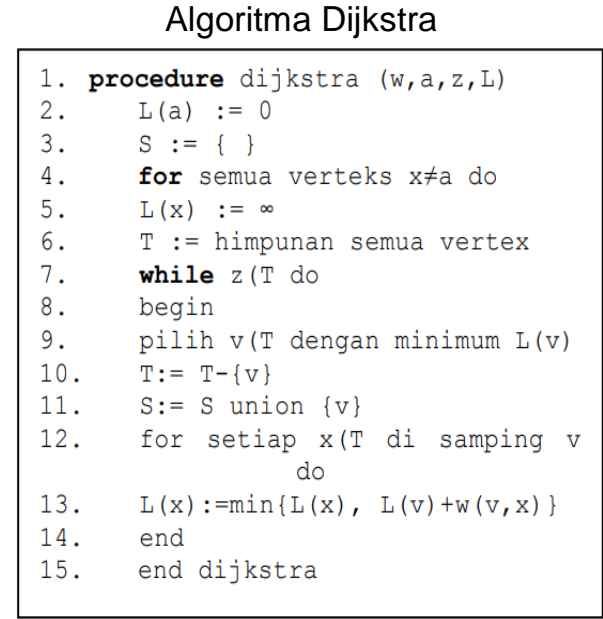

Gambar 1. Contoh Pseudocode Dari Algoritma Dijkstra Sumber: (Dewi, 2010)

Padatnya urbaninsasi penduduk mempengaruhi kemacetan lalu lintas Jakarta. Banyak langkah-langkah yang sudah dilakukan pemerintah dalam menangani permasalahan ini. Walaupun ada pengurangan kemacetan, tetap saja Jakarta masih termasuk wilayah kemacetan yang tinggi. Sebagai pengguna jalan harus mencari solusi lain yaitu dengan menentukan jalan-jalan manakah yang harus dilalui sehingga kita dapat mencari tempat tujuan dengan jarak terpendek atau mencari jalur terdekat (Wibowo \& Wicaksono, 2012).

Wilayah Pasar Minggu merupakan nama salah satu Kelurahan di Kecamatan Pasar Minggu Kota Jakarta Selatan Provinsi DKI Jakarta. Pemilihan nama wilayah ini berdasarkan alamat domisili penulis yaitu $\mathrm{J}$. M No.2A Rawa Bambu I RT.007 RW.06 Kelurahan Pasar Minggu Kecamatan Pasar Minggu Kota Jakarta Selatan Provinsi DKI Jakarta. Titik awal rute dalam penelitian ini adalah JI. M Rawa Bambu I RT.007 RW.06 Pasar Minggu Kota Jakarta Selatan, Provinsi DKI Jakarta.

Rumusan masalah dari latar belakang tersebut yaitu penentuan rute terpendek wilayah Pasar Minggu dengan STMIK Nusa Mandiri Kramat Jakarta, menerapkan Algoritma Dijkstra untuk melakukan kalkulasi terhadap semua kemungkinan bobot terkecil dari setiap titik.

Sedangkan batasan masalah dalam penelitian ini adalah: 1) Pencarian rute terpendek dengan menggunakan algoritma dijkstra dibatasi hanya pada permasalahan shortest path, dengan input graph yang terdiri dari jumlah titik atau titik, nama wilayah dan titik koordinat; 2) bobot yang digunakan pada setiap titik adalah bobot jarak. Sehingga rute terpendek berdasarkan jarak lintasa terpendek antar titik; 3) Dalam penggunaan Algoritma Dijkstra ini tidak dibahas kecepatan transportasi dan waktu dari titik awal ke titik tujuan; dan 4) Data yang digunakan bersumber dari informasi yang merujuk pada kondisi sebenarnya.

Manfaat Algoritma Dijkstra untuk mencari lintasan terdekat (Fitria \& Triansyah, 2013), maka dapat membantu para pengguna untuk mengetahui jalur terdekat tanpa harus membuang-buang waktu. Sedangkan tujuan dari penelitian ini antara lain: 1) memberikan solusi dalam pemilihan lintasan terpendek pada wilayah Pasar Minggu - STMIK Nusa Mandiri Kramat Jakarta; 2) mempercepat dalam mencari solusi lintasan terpendek antara wilayah Pisangan - STMIK Nusa Mandiri Kramat Jakarta; dan 3) memperoleh hasil yang akurat dan tepat sesuai dengan keadaan di lapangan.

\section{Metode Penelitian}

Algoritma dijkstra merupakan algoritma yang sering digunakan dalam menetukan rute terpendek, mudah digunakan dengan menggunakan titik sederhana pada lintasan jalan yang tidak rumit (Primadasa, 2015).

Prinsip algoritma Dijkstra adalah mencari dua jalur terkecil (The principle of Dijkstra's algorithm is to search for the two smallest paths) (Lestari et al., 2020). Algoritma Dijkstra memiliki iterasi untuk mencari titik yang jaraknya paling pendek dari titik awal (Dwi, Saputra \& Ardana, 2016).

Berdasarkan orientasi arah pada sisi, maka secara umum graf dibedakan atas 2 jenis (Satyanuraga, 2015):

1) Graf tak-berarah (undirected graf)

Graf tak-berarah adalah graf dimana setiap sisinya tidak memiliki orientasi arah.

2) Graf berarah (directed graf or digraf) Graf berarah adalah graf dimana setiap sisinya memiliki orientasi arah

Prinsip greedy pada Algoritma Dijkstra menyatakan bahwa pada setiap langkah kita memilih sisi yang berbobot minimum dan memasukannya dalam himpunan solusi (Andayani \& Perwitasari, 2014). 
Misalkan $A$ merupakan graf berarah berlabel dengan titik-titik $\mathrm{V}(\mathrm{A})=\{\mathrm{v} 1$, v2, v3 $\mathrm{n \}}$ dan jalur lintasan terpendek yang akan dicari adalah dari v1 ke vn. Proses pencarian algoritma ini dimulai dari titik v1. Dalam iterasinya algoritma dijkstra akan mencari satu titik berikutnya yang jumlah bobotnya paling kecil dari titik sebelumnya. Titik-titik yang sudah terpilih dipisahkan dan titik-titik tersebut tidak diperhatikan lagi pada iterasi berikutnya (Fitria \& Triansyah, 2013).

Misalkan :

$\mathrm{V}(\mathrm{A})=\{\mathrm{v} 1, \mathrm{v} 2, \mathrm{v} 3 \ldots \mathrm{vn}\}$

$L \quad=$ himpunan titik-titik $\in V(A)$ yang sudah terpilih dalam lintasan path terpendek

$B(j) \quad=$ jumlah bobot lintasan terkecil dari v1 ke vj

$\mathrm{G}(\mathrm{i}, \mathrm{j}) \quad=$ bobot garis dari titik vi ke titik vj

$G^{*}(1, j)=$ jumlah bobot path terkecil dari $v 1$ ke vj

Secara formal, penggunaan algoritma Dijkstra untuk mencari shortest path adalah sebagai berikut:

1) $L=\{\}$;

2) $V=\{v 2, v 3, \ldots, v n\}$

3) Untuk $i=2, \ldots, n$, lakukan $B(i)-G(1, i)$

4) Selama vn $\notin L$ lakukan:

a. Pilih titik $v k \in V-L$ dengan $B(k)$ terkecil. $\mathrm{L}=\mathrm{L} \cup\{\mathrm{vk}\}$

b. Untuk setiap vj $\in \mathrm{V}$ - L lakukan: Jika $\mathrm{B}(\mathrm{j})>\mathrm{B}(\mathrm{k})+\mathrm{G}(\mathrm{k}, \mathrm{j})$ maka ganti $\mathrm{B}(\mathrm{j})$ dengan $B(k)+G(k, j)$

5) Untuk setiap vj $\in \mathrm{V}, \mathrm{G}^{*}(1, \mathrm{j})=\mathrm{K}(\mathrm{j})$

Menurut algoritma di atas, jalur lintasan pendek dari titik $v_{1}$ ke $v_{n}$ adalah melalui titik-titik dalam $\mathrm{L}$ secara berurutan, dan jumlah bobot rute terkecilnya adalah $B(n)$.

Dalam penelitian ini pendekatan yang dilakukan adalah menggunakan pendekatan kualitatif. Artinya data yang dikumpulkan bukan berupa nilai dan angka, melainkan data tersebut berasal dari catatan, naskah, dokumen pribadi, catatan lapangan, memo dan dokumen pendukung berupa dokumen resmi lainnya. Sehingga yang menjadi tujuan dari penelitian kualitatif ini adalah menggambarkan realita empirik dibalik fenomena secara mendalam, rinci dan tuntas. Pendekatan kualitatif yang digunakan dalam penelitian ini adalah dengan melihat kecocokan antara realita empirik dengan teori-teori yang berlaku dengan menggunakan metode deskriptif.
Metode yang digunakan untuk proses pengumpulan data dalam penelitian ini adalah:

1. Metode Pengamatan Langsung (Observation)

2. Dalam metode ini peneliti melakukan perjalanan secara langsung dari wilayah Pasar Minggu ke Kampus STMIK Nusa Mandiri Kramat Jakarta untuk mengukur jarak melalui empat rute.

3. Metode pengambilan titik waypoint Dalam metode ini, penelitian menggunakan alat Global Positioning System (GPS).

4. Metode Studi Pustaka (Library Research) Pada tahap ini peneliti mencatat dan mengutip pendapat beberapa ahli dan nara sumber dalam artikel, buku serta surat kabar untuk memperkuat landasan teori.

\section{Hasil dan Pembahasan}

Algoritma Dijkstra menggunakan prinsip greedy dalam menentukan jalur lintasan terpendeknya. Pada setiap langkah, ambil sisi berbobot terkecil dengan menghubungkan sebuah simpul yang sudah terpilih dengan sebuah simpul lain yang belum terpilih. Lintasan dari titik simpul asal ketitik simpul yang baru haruslah merupakan lintasan yang terpendek di antara semua lintasannya ke titik simpul-simpul yang belum terpilih (Novandi, 2013).

Penelitian ini menghasilkan suatu program yang mengimplementasikan Algoritma Dijkstra untuk pencarian rute atau jalur terpendek wilayah Pasar Minggu STMIK Nusa Mandiri Kramat Jakarta.

Berikut adalah langkah-langkah pencarian lintasan terpendek menggunakan algoritma dijkstra :

1. Beri nilai bobot (jarak) untuk setiap titik ketitik lainnya, lalu set nilai 0 pada titik awal dan nilai tak terhingga terhadap titik lain (belum terisi).

2. Set semua titik dari rute yang ditentukan dengan "Belum Terjamah" dan set titik awal rute perjalanan sebagai "titik awal keberangkatan".

3. Dari titik keberangkatan, pertimbangkan titik tetangga yang belumterjamah dan hitung jaraknya dari titik keberangkatan. Sebagai contoh, jika titik keberangkatan A ke B memiliki bobot jarak 8 dan dari B ke titik $C$ berjarak 3 , maka jarak ke $C$ melewati $B$ menjadi $8+3=11$. Jika jarak ini lebih kecil dari jarak sebelumnya (yang 
telah terekam sebelumnya) hapus data lama, simpan ulang data jarak dengan jarak yang baru.

4. Saat kita selesai mempertimbangkan setiap jarakterhadap titik tetangga, tandai titik yang telah terjamah sebagai "Titik Terjamah". Titik terjamah tidak akan pernah dicek kembali, jarak yang disimpan adalah jarak terakhir dan yang paling minimal bobotnya.

5. Set "Titik Belum Terjamah" dengan jarak terkecil (dari titik keberangkatan) sebagai "Titik Keberangkatan" selanjutnya dan lanjutkan dengan kembali ke step 3.

Terdapat pilihan rute-rute yang dapat dilalui, diantaranya sebagai berikut:

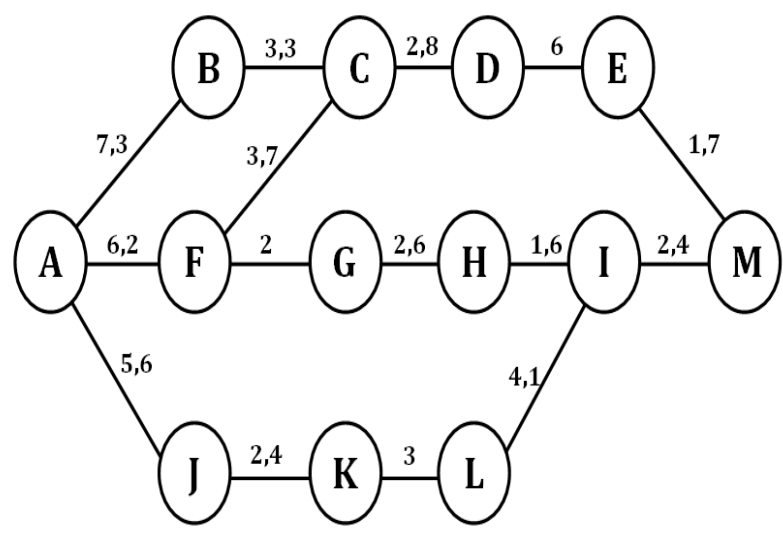

Gambar 2. Rute Pasar Minggu-Kampus STMIK Nusa MandiriKramat Jakarta Sumber: Panggabean (2020)

Keterangan :

A : Pasar Minggu

B : MampangPrapatan

C : Kuningan

D : Menteng

E : Cikini

$\mathrm{F}$ : Pancoran

G : Tebet

$\mathrm{H}$ : Manggarai

I : Salemba

$\mathrm{J}:$ Kalibata

$\mathrm{K}$ : Cawang

$\mathrm{L}$ : Jatinegara

M : Kampus STMIK Nusa MandiriKramat Jakarta

Berikut adalah tabel rute perjalanan dari Pasar Minggu ke Kampus STMIK Nusa Mandiri Kramat Jakarta:
Tabel 1. Rute 1

\begin{tabular}{|c|c|c|}
\hline Rute 1 & Titik Yang Dipilih & Jarak \\
\hline $\begin{array}{l}\text { Pasar } \\
\text { Minggu }\end{array}$ & $\begin{array}{l}\text { JI. M Rawa Bambu I RT.007 } \\
\text { RW.06 Pasar Minggu, Kota } \\
\text { Jakarta Selatan, } \\
\text { DKI Jakarta }\end{array}$ & $0 \mathrm{~km}$ \\
\hline $\begin{array}{l}\text { Mampang } \\
\text { Prapatan }\end{array}$ & $\begin{array}{l}\text { Mampang Square, } \\
\text { JI. Mampang Prpt. Raya } \\
\text { No.88, RT.4 RW.6, Kel. } \\
\text { Tegal Parang, Kec. } \\
\text { Mampang Prapatan, Kota } \\
\text { Jakarta Selatan, DKI Jakarta }\end{array}$ & $7,3 \mathrm{~km}$ \\
\hline Kuningan & $\begin{array}{l}\text { Kedutaan Besar Malaysia, } \\
\text { JI. H. R. Rasuna Said } \\
\text { Kav.X/6 No.1-3 RT.7 RW.4, } \\
\text { Kel. Kuningan, Kec.Karet } \\
\text { Kuningan, Kota Jakarta } \\
\text { Selatan, DKI Jakarta }\end{array}$ & $3,3 \mathrm{~km}$ \\
\hline Menteng & $\begin{array}{l}\text { KedutaanBesar Iran, } \\
\text { Jl. Hos. Cokroaminoto } \\
\text { No.110, RT.10 RW.4, Kel. } \\
\text { Menteng Kec. Menteng, Kota } \\
\text { Jakarta Pusat. DKI Jakarta }\end{array}$ & $2,8 \mathrm{~km}$ \\
\hline Cikini & $\begin{array}{l}\text { Rumah Sakit PGI Cikini, } \\
\text { JI. Raden Saleh Raya } \\
\text { No.40, RT.12 RW.2, Cikini, } \\
\text { Kec. Menteng, Kota Jakarta } \\
\text { Pusat, DKI Jakarta }\end{array}$ & $6 \mathrm{~km}$ \\
\hline $\begin{array}{l}\text { Kampus } \\
\text { STMIK }\end{array}$ & $\begin{array}{l}\text { Jl. Kramat Raya No.18, RT.5 } \\
\text { RW.7, Kel. Kwitang, Kec. } \\
\text { Senen, Kota Jakarta Pusat, } \\
\text { DKI Jakarta }\end{array}$ & $1,7 \mathrm{~km}$ \\
\hline & & $\begin{array}{l}21,1 \\
\mathrm{~km}\end{array}$ \\
\hline
\end{tabular}

Sumber: Panggabean (2020)

Tabel 2.Rute 2

\begin{tabular}{|l|l|l|}
\hline Rute 2 & Titik Yang dipilih & Jarak \\
\hline Pasar \\
Minggu & $\begin{array}{l}\text { Jl. M Rawa Bambu I RT.007 } \\
\text { RW.06 Pasar Minggu, Kota } \\
\text { Jakarta Selatan, DKI Jakarta }\end{array}$ & o km \\
\hline Pancoran & $\begin{array}{l}\text { Monumen Patung } \\
\text { Dirgantara } \\
\text { Jl. Gatot Subroto RT.2 RW.1 } \\
\text { Kel. Menteng Dalam, Kec. } \\
\text { Pancoran, Kota Jakarta } \\
\text { Selatan }\end{array}$ & $6,2 \mathrm{~km}$ \\
\hline Kuningan & $\begin{array}{l}\text { Kedutaan Besar Malaysia, } \\
\text { Jl. H. R. Rasuna Said } \\
\text { Kav.X/6 No.1-3 RT.7 RW.4 } \\
\text { Kel. Kuningan, Kec. Karet } \\
\text { Kuningan, Kota Jakarta } \\
\text { Selatan, DKI Jakarta }\end{array}$ & 3,7 km \\
\hline Menteng & $\begin{array}{l}\text { Kedutaan Besar Iran, } \\
\text { Jl. HOS. Cokroaminoto } \\
\text { No.110 RT.10 RW.4, Kel. } \\
\text { Menteng, Kec. Menteng, } \\
\text { Kota Jakarta Pusat, DKI } \\
\text { Jakarta }\end{array}$ & 2,8 km \\
\hline
\end{tabular}




\begin{tabular}{|l|l|c|}
\hline Rute 2 & Titik Yang dipilih & Jarak \\
\hline Cikini & $\begin{array}{l}\text { RumahSakit PGI Cikini, } \\
\text { Jl. Raden Saleh Raya } \\
\text { No.40, RT.12 RW.2, Kel. } \\
\text { Cikini, Kec. Menteng, Kota } \\
\text { Jakarta Pusat, DKI Jakarta }\end{array}$ & $6 \mathrm{~km}$ \\
\hline $\begin{array}{l}\text { Kampus } \\
\text { STMIK }\end{array}$ & $\begin{array}{l}\text { Jl. Kramat Raya No.18, } \\
\text { RT.5 RW.7, Kel. Kwitang, } \\
\text { Kec. Senen, Jakarta } \\
\text { Pusat, DKI Jakarta }\end{array}$ & $1,7 \mathrm{~km}$ \\
\hline & & $\begin{array}{c}20,4 \\
\mathrm{~km}\end{array}$ \\
\hline
\end{tabular}

Sumber: Panggabean (2020)

Tabel 3.Rute 3

\begin{tabular}{|l|l|c|}
\hline Rute 3 & Titik Yang dipilih & Jarak \\
\hline $\begin{array}{l}\text { Pasar } \\
\text { Minggu }\end{array}$ & $\begin{array}{l}\text { Jl. M Rawa Bambu I } \\
\text { RT.007 RW.06 Pasar } \\
\text { Minggu, Jakarta Selatan }\end{array}$ & $0 \mathrm{~km}$ \\
\hline Pancoran & $\begin{array}{l}\text { Monumen Patung } \\
\text { Dirgantara }\end{array}$ & $6,2 \mathrm{~km}$ \\
\hline Tebet & $\begin{array}{l}\text { Kantor Pelayanan Pajak } \\
\text { Tebet } \\
\text { Jl.Tebet Raya No. 9, RT.13 } \\
\text { RW.2, Kel. Tebet Barat, } \\
\text { Kec. Tebet, Jakarta } \\
\text { Selatan, DKI Jakarta }\end{array}$ & $2 \mathrm{~km}$ \\
& $\begin{array}{l}\text { Pasaraya Manggarai } \\
\text { Jl. Sultan Agung No.1, } \\
\text { RT.2/RW.8, Ps. Manggis, } \\
\text { Kec. Tebet, Kota Jakarta } \\
\text { Selatan, DKI Jakarta }\end{array}$ & $2,6 \mathrm{~km}$ \\
\hline Salemba & $\begin{array}{l}\text { BMN Connected Indonesia } \\
\text { Jl. Salemba Raya No.28, } \\
\text { RT.5 RW.6, Kel. Kenari, } \\
\text { Kec. Senen, Jakarta Pusat, } \\
\text { DKI Jakarta }\end{array}$ & $1,6 \mathrm{~km}$ \\
\hline Kampus & $\begin{array}{l}\text { Jl. Kramat Raya No.18, RT.5. } \\
\text { RW.7, Kel. Kwitang, Kec. } \\
\text { STMIK } \\
\text { Senen, Jakarta Pusat, DKI }\end{array}$ & $2,4 \mathrm{~km}$ \\
\hline \multirow{2}{*}{ Jakarta }
\end{tabular}

Sumber: Panggabean (2020)

Tabel 4.Rute 4

\begin{tabular}{|l|l|c|}
\hline Rute 4 & Titik Yang dipilih & Jarak \\
\hline Pasar \\
MInggu & $\begin{array}{l}\text { JI. M Rawa Bambu I RT.007 } \\
\text { RW.06 Pasar Minggu, Kota } \\
\text { Jakarta Selatan, DKI } \\
\text { Jakarta }\end{array}$ & 0 km \\
\hline Kalibata & $\begin{array}{l}\text { Taman Makam Pahlawan } \\
\text { Nasional Utama } \\
\text { JI. Raya Kalibata No.14, } \\
\text { RT.14 RW.1, Kel. Kalibata, } \\
\text { Kec. Pancoran, Jakarta } \\
\text { Selatan, DKI Jakarta }\end{array}$ & $5,6 \mathrm{~km}$ \\
\hline Cawang & $\begin{array}{l}\text { RSUD BUDHI ASIH } \\
\text { JI. DewiSartika No.200, } \\
\text { RT.1 RW.3, Kel. Cawang } \\
\text { III, Kec. Kramatjati, Jakarta } \\
\text { Timur, DKI Jakarta }\end{array}$ & 2,4 km \\
\hline
\end{tabular}

\begin{tabular}{|c|c|c|}
\hline Rute 4 & Titik Yang dipilih & Jarak \\
\hline Jatinegara & $\begin{array}{l}\text { Politeknik Statistika STIS } \\
\text { Jalan Otto Iskandardinata } \\
\text { No.64C } 14, \text { RT.1 RW.4, Kel. } \\
\text { Bidara Cina, Kec. } \\
\text { Jatinegara, Jakarta Timur, } \\
\text { DKI Jakarta }\end{array}$ & $3 \mathrm{~km}$ \\
\hline Salemba & $\begin{array}{l}\text { BMN Connected Indonesia, } \\
\text { JI. Salemba Raya No.28, RT.5 } \\
\text { RW.6, Kel. Kenari, Kec. } \\
\text { Senen, Kota Jakarta Pusat, } \\
\text { DKI Jakarta }\end{array}$ & $4,1 \mathrm{~km}$ \\
\hline $\begin{array}{l}\text { Kampus } \\
\text { STMIK }\end{array}$ & $\begin{array}{l}\text { Jl. Kramat Raya No.18, RT.5 } \\
\text { RW.7, Kel. Kwitang, Kec. } \\
\text { Senen, Kota Jakarta Pusat, } \\
\text { DKI Jakarta }\end{array}$ & $2,4 \mathrm{~km}$ \\
\hline & & $\begin{array}{c}17,5 \\
\mathrm{~km}\end{array}$ \\
\hline
\end{tabular}

Sumber: Panggabean (2020)

Total jarak pada rute pertama adalah $21,1 \mathrm{~km}$, jarak yang paling jauh adalah Pasar Mingggu menuju Mampang Prapatan. Total jarak pada rute kedua adalah $20,4 \mathrm{~km}$, jarak yang paling jauh adalah Pasar Minggu menuju Pancoran. Total Jarak pada rute ketiga adalah $14,8 \mathrm{~km}$, jarak yang paling jauh adalah Pasar Minggu menuju Pancoran. Total Jarak pada rute keempat adalah $17,5 \mathrm{~km}$, jarak yang paling jauhadalah Pasar Minggu menuju Kalibata.

Dalam hal ini pengguna jalan dapat memilih jalur ketiga yang diasumsikan sebagai jalur terpendek untuk rute Pasar Minggu ke STMIK Nusa Mandiri Kramat Jakarta

Perhitungan lintasan terpendek dari titik simpul awal A ke titik simpul M : 1. Langkah Pertama Perhitungan
Menggunakan Algoritma Dijkstra

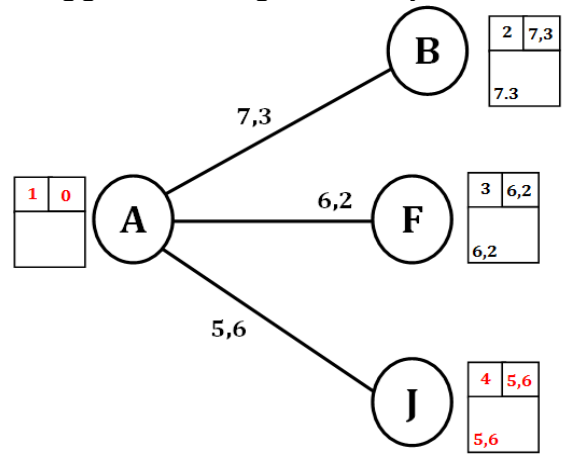

Gambar 3. Langkah Pertama Perhitungan Menggunakan Algoritma Dijkstra

Sumber: Panggabean (2020)

Keterangan:

Menghitung jarak terpendek dengan membandingkan titik awal $\mathrm{A}=$ Pasar Minggu dengan titik $\mathrm{B}=$ Mampang Prapatan, $\mathrm{F}=$ 
Pancorandan $\mathrm{J}=$ Kalibata. Dan akhirnya titik yang dituju untuk selanjutnya adalah titik $\mathrm{F}=$ Kalibata karena memiliki jarak yang paling kecil.

2. Langkah Kedua Perhitungan Menggunakan Algoritma Dijkstra

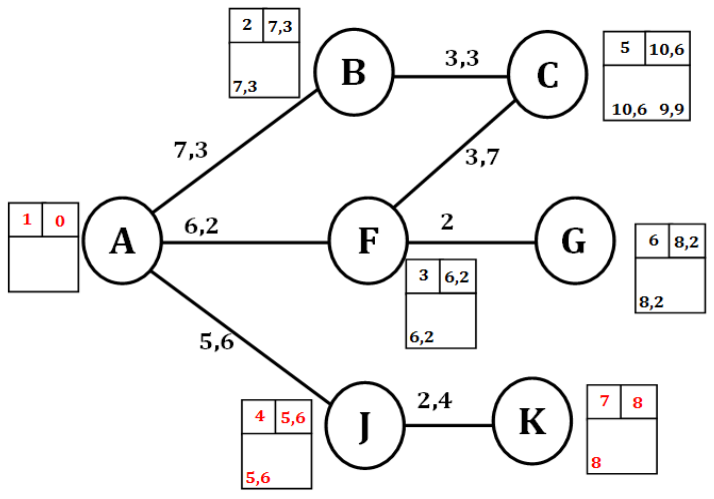

Gambar 4. Langkah Kedua Perhitungan

Menggunakan Algoritma Dijkstra

Sumber: Panggabean (2020)

Keterangan:

Menghitung jarak terpendek dari titik $B=$ Mampang Prapatan ke $\mathrm{C}=$ Kuningan, $\mathrm{F}=$ Kalibata ke $\mathrm{C}=$ Kuningan, $\mathrm{F}=$ Kalibata ke $\mathrm{G}$ $=$ Tebet dan $\mathrm{J}=$ Kalibatake $\mathrm{K}=$ Cawang. Dan akhirnyatitik yang dituju untuk selanjutnya adalah titik $\mathrm{K}=$ Cawang karena memiliki jarak yang paling kecil.

3. Langkah Ketiga Perhitungan Menggunakan Algoritma Dijkstra

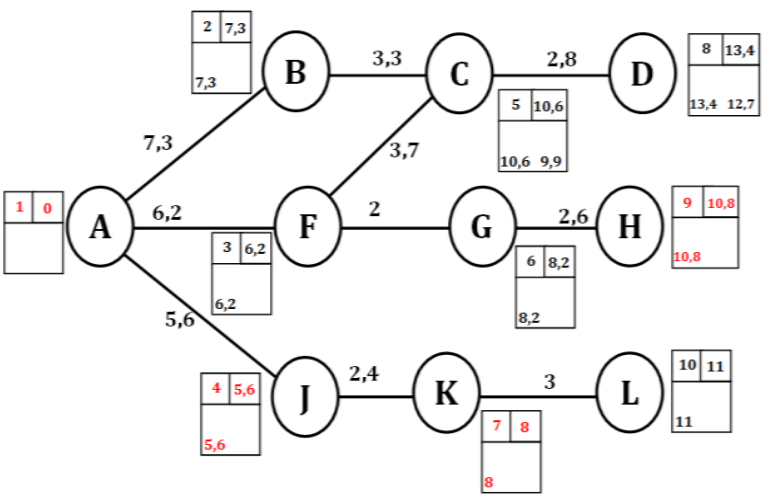

Gambar 5. Langkah Ketiga Perhitungan

Menggunakan Algoritma Dijkstra

Sumber: Panggabean (2020)

Keterangan:

Menghitung jarak terpendek dari titik $C=$ Kuningan ke $\mathrm{D}=$ Menteng, $\mathrm{G}=$ Tebet ke $\mathrm{H}=$ Manggarai dan $\mathrm{K}=$ Cawang $\mathrm{ke} \mathrm{L}=$ Jatinegara. Hasil perbandingan rute tersebut akhirnya titik yang dituju untuk selanjutnya adalah titik $\mathrm{H}=$ Manggarai karena memiliki jarak yang paling kecil. Dan jarak yang telah terekam sebelumnya di hapus simpan ulang data jarak dengan jarak yang baru.

4. Langkah $\mathrm{Ke}$ Empat Perhitungan Menggunakan Algoritma Dijkstra

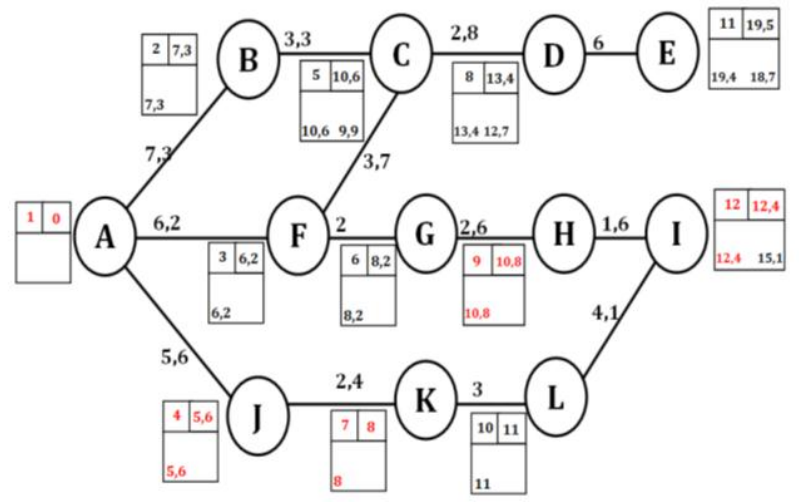

Gambar 6. Langkah Ke Empat Perhitungan Menggunakan Algoritma Dijkstra Sumber: Panggabean (2020)

\section{Keterangan:}

Menghitung jarak terpendek dari titik $D=$ Menteng ke $\mathrm{E}=$ Cikini, $\mathrm{H}=$ Manggarai ke $\mathrm{I}=$ Salemba dan $\mathrm{L}=$ Jatine gara ke $\mathrm{I}=$ Salemba. Dan akhirnya titik yang dituju untuk selanjutnya adalah titik $\mathrm{I}=$ Salemba karena memiliki jarak yang paling kecil.

5. Langkah Kelima Perhitungan

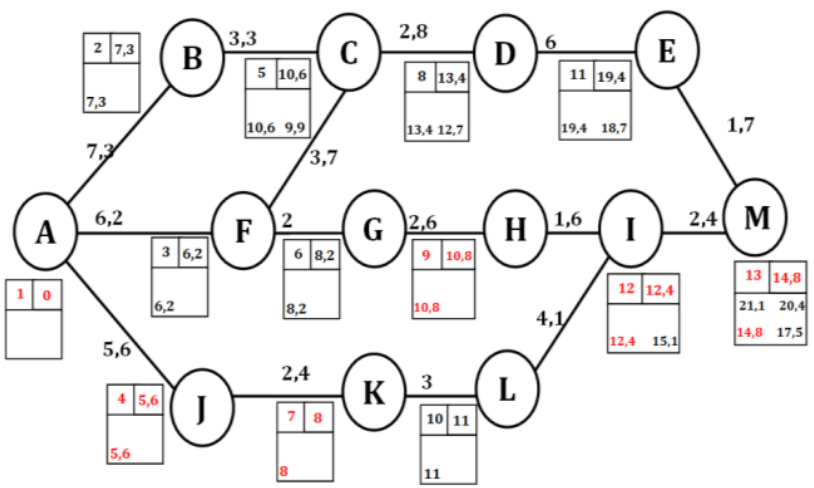

Gambar 7. Langkah Ke Lima Perhitungan

Menggunakan Algoritma Dijkstra

Sumber: Panggabean (2020)

Keterangan:

Menghitung jarak terpendek dari titik $\mathrm{E}=$ Cikinike $\mathrm{M}=$ Kampus STMIK Nusa Mandiri Kramat Jakarta dan I = Salemba ke $\mathrm{M}=$ Kampus STMIK Nusa Mandiri Kramat Jakarta. 
Jadi rute terpendek dari Wilayah Pasar Minggu menuju STMIK Nusa MandiriKramat Jakarta adalah 14,8 km melalui Pancoran, Tebet, Manggarai, Salemba dan berakhir di Kampus STMIK Nusa Mandiri Kramat Jakarta.

\section{Kesimpulan}

Berdasarkan dari pembahasan diatas maka dapat disimpulkan bahwa untuk mencari jalur rute terpendek antara wilayah Pasar Minggu dengan STMIK Nusa Mandiri Kramat Jakarta sudah ditemukan rutenya, yaitu rute ketiga dengan jarak tempuh 14,8 $\mathrm{km}$. Namun hasil ini tidak menjamin pengguna jalan cepat sampai ketempat tujuan melainkan peluangnya lebih besar. Maka diharapkan pengguna jalan dapat dengan bijak memilih jalur atau rute yang ditempuh untuk mencapai tempat tujuan yang diinginkan.

\section{Referensi}

Andayani, S., \& Perwitasari, E. W. (2014). Penentuan Rute Terpendek Pengambilan Sampah di Kota Merauke Menggunakan Algoritma Dijkstra. Aeminar Nasional Teknologi Informasi \& Komunikasi Terapan (SEMANTIK).

Dewi, L. J. E. (2010). Pencarian Rute Terpendek Tempat Wisata Di Bali Dengan Menggunakan Algoritma Dijkstra. Seminar Nasional Aplikasi Teknologi Informasi 2010 (SNATI 2010).

Dwi, Saputra, R., \&Ardana. (2016). Penerapan Algoritma Dijkstra pada Aplikasi PencarianRute Bus Trans Semarang. Skripsi Jurusanl ImuKomputer, Fakultas Sains Dan Matematika, Universitas Diponegoro.

Fitria, \& Triansyah, A. (2013). Implementasi Algoritma Dijkstra Dalam Aplikasi Untuk Menentukan Lintasan Terpendek Jalan Darat Antar Kota Di Sumatera Bagian Selatan. Jurnal Sistem Informasi (JIS).

Lestari, S. L., Ardiansyah, A., Giovani, A. P., \& Dwijayanti, D. (2020). A Dijkstra Algorithm Implementation In Determining Shortest Route To Mosque In Residential Citra Indah City. Jurnal Pilar Nusa Mandiri. https://doi.org/10.33480/pilar.v16i1.1 199

Munir, R. (2016). Algoritma Dan Pemrograman Dalam Bahasa Pascal, C, Dan C++ Edisi Keenam. Informatika. Bandung.

Novandi, R. A. D. (2013). Perbandingan Algoritma Dijkstra dan Algoritma Floyd-Warshalldalam Penentuan Lintasan Terpendek( Single Pair Shortest Path ). IF2251 Strategi Algoritmik.

Primadasa, Y. (2015). Pencarian Rute Terpendek Menggunakan Algoritma Dijkstra Pada Sig Berbasis Web Untuk Distribusi Minuman. JurnalKomTekInfollmuKomputer.

Satyanuraga, D. (2015). PenerapanTeori Graf Dalam Rencana Tata Ruang Kota. Makalah IF2120 Matematika Diskrit-Sem. I Tahun.

Wibowo, A. G., \&Wicaksono, A. P. (2012). Rancang Bangun Aplikasi untuk Menentukan Jalur Terpendek RumahSakit di Purbalingga dengan Metode Algoritma Dijkstra. Juita. 